\title{
Prenatal diagnosis of a "living" oropharyngeal fetus in fetu: a case report
}

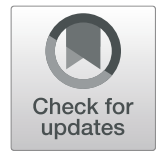

\author{
Ling Wang ${ }^{1}$, Baiguo Long ${ }^{1}$, Qichang Zhou ${ }^{2}$ and Shi Zeng ${ }^{2^{*}}$ (D)
}

\begin{abstract}
Backgroud: Fetus in fetu (FIF) is a rare malformation in which a parasitic twin within its more mature twin. Most of the FIF locate in the retroperitoneum and are acardiac and anencephalic.

Case presentation: Here, we describe a unique case of oropharyngeal fetus in fetu with a rudimentary twochambered heart detected by prenatal ultrasonography. The parents terminated this pregnancy after counseling. Macroscopic examination found a solid mass between the oral and fetal chest, with a rudimentary two-chambered heart at the lowest part of the mass. Microscopic findings showed amniotic membrane, skin, cartilage, gastrointestinal and neural tissue.

Conclusions: Prenatal ultrasound can identify rudimentary organs suspecting FIF from early pregnancy. Detection of fetal heart beat facilitates differential diagnosis with teratomas, providing essential information for parental consulting and management.
\end{abstract}

Keywords: Fetus in fetu, Prenatal, Oropharyngeal

\section{Introduction}

Fetus in fetu (FIF), fetiform masses enclosed within the body of the relatively normal fetus, is the one of internal forms of parasitic twin [1]. As reported initially in 1935 [2], FIF was described as "as a mass containing a vertebral axis often associated with other organs around this axis". With the increased reports and advanced knowledge, the presence of spinal column wasn't the necessity for diagnosis any more. The characteristics of FIF include a mass enclosed within a distinct fibrous membrane, partially or completely covered by normal skin, grossly recognizable anatomic structures and supplied by a relatively large blood vessel from the host fetus $[1,3$, 4]. Moreover, the presence of grossly recognizable anatomic structures is the key point for differentiating FIF from another internal form of parasitic twin- teratoma. A teratoma, on the other hand, is germ cell tumor without high level of organization and unable to develop mature tissue [1]. Complete surgical resection of the mass is the main management for FIF. The prognosis of FIF is

\footnotetext{
* Correspondence: shizeng@csu.edu.cn; doctorzshi@163.com

${ }^{2}$ Department of Ultrasound Diagnosis, The Second Xiangya Hospital of Central South University, 139 Renmin Road (M), Changsha 410011, Hunan, China

Full list of author information is available at the end of the article
}

generally favorable based on its typical benign feature although there was an atypical potentially malignant case reported [5].

FIF is a rare malformation, generally acardiac and anencephalic, with frequent localization in the retroperitoneum. Here, we describe a unique case of oropharyngeal fetus in fetu with a rudimentary two-chambered heart detected. Prenatal ultrasound is a useful tool to identify well developed organs in the FIF, evaluate the size and spatial relationship of the mass, and help to guide the ex utero intrapartum treatment procedure for newborn FIF $[6,7]$, or offer the reasonable option of early termination for severe cases.

\section{Case presentation}

A 28-year-old, gravida 1 para 0 woman was referred for routine obstetric ultrasound scan at 16 weeks' gestation. The family history was negative for congenital malformations, and there was no history of medication and drug use during pregnancy. The biometry measurements were appropriate for gestation age. A nonhomogeneous mass, protruding out of the mouth, was identified in the fetus oropharyngeal section (Fig. 1). The mass was about $32 \mathrm{~mm} \times 27 \mathrm{~mm} \times 28 \mathrm{~mm}$, with the lower part locating in the fetal chest and upper part locating in fetal oral 

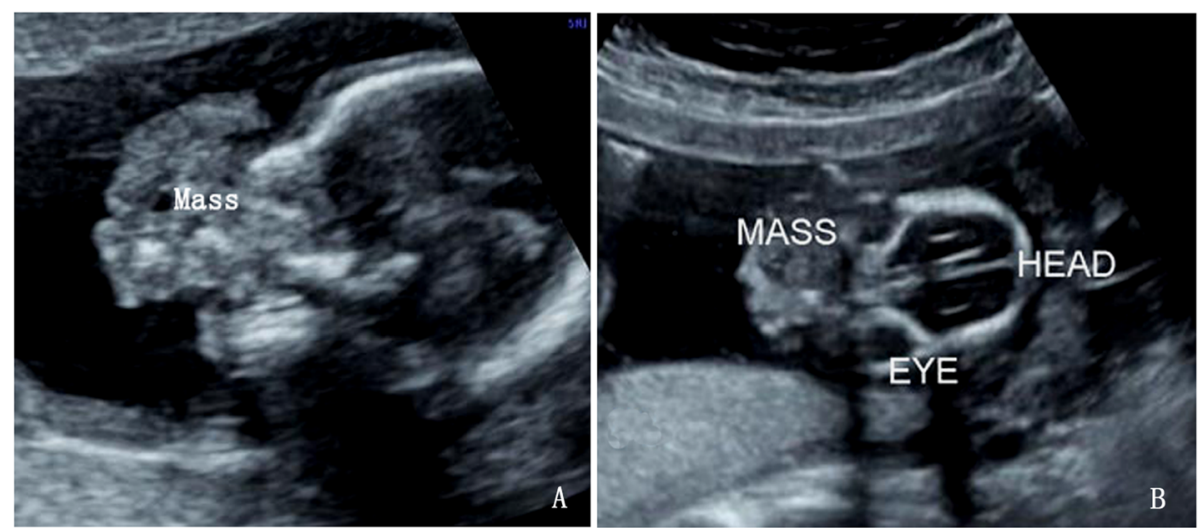

Fig. 1 A nonhomogeneous mass, protruding out of the mouth, was identified in the fetus oropharyngeal section. a sagittal view; b coronal view

cavity. A two-chamber beating heart-like structure was demonstrated at the lowest end of the mass within the fetal left chest. Doppler demonstrated pulsatile color signals in the heart-like structure (Fig. 2). The heart of the fetus was demonstrated on the right chest. Multiple calcifications were also noted in the mass. Besides, the hard palate and superior alveolar bone were absent. The amniotic fluid index and umbilical artery pulsatility index were normal. Fetus in fetu was suspected considering the heart-like structure in the mass. The parents terminated this pregnancy after counseling. The fetal karyotype was 46,XX. Macroscopic examination found a solid mass between the oral and fetal chest, with a rudimentary two-chambered heart at the lowest part of the mass (Fig. 3). Microscopic findings showed amniotic membrane, skin, cartilage, gastrointestinal and neural tissue.

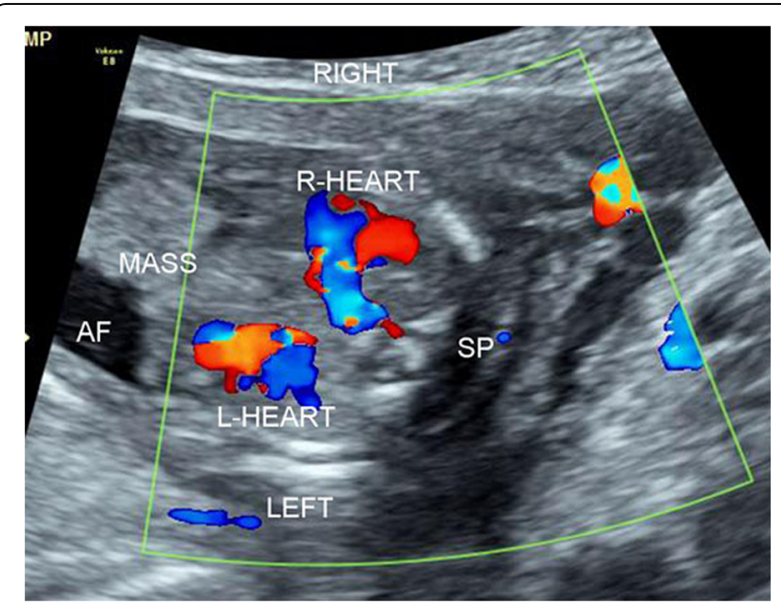

Fig. 2 Color Doppler demonstrated pulsive color signals in the heart-like structure at the lowest end of the mass within the fetal left chest. The heart of the fetus was demonstrated on the right chest. AF, amniotic fluid; Sp, spine

\section{Discussion and conclusions}

The presence of well differentiated organogenesis is the key feature in the FIF. Vertebral column and limbs were the most recognizable structures in FIF. Skin, intestinal, bones, cartilage, lung, and adrenal tissue were also often present. A review [4] of reported 32 prenatal cases of FIF concluded that $90 \%$ of cases had a vertebral column, $90 \%$ had recognize bony extremity or rudimentary limb, $60 \%$ had central nervous tissue, $26 \%$ had gastrointestinal tissue, and $20 \%$ had respiratory tissue. All of reported FIF were acardiac except one case which found rudimentary heart structure by postnatal ultrasound [6]. To date, the present case is the first FIF with cardiac structure detected prenatally. Actually, except for the heart structure, there was no obvious vertebral column, extremity limb and bone or other recognizable organs in our case. The presence of two chamber heart in the mass was the important clue for the diagnosis of FIF in this case and was confirmed by autopsy.

FIF mostly located within the abdomen (80\%), skull (8\%) and sacral region (8\%) [4]. The location of oral/ oropharyngeal was only reported in two prenatal cases $[7,8]$. Although the mass in FIF was benign, it may compress surrounding tissues and cause destructive lesions and maldevelopment of surrounding organs. In this case, the hard palate and superior alveolar bone were absent which may related to the existence of FIF. Lindsey M's review reported $97 \%$ of FIF had a good prognosis after complete surgical resection of the parasitic twin [9]. Few adverse outcomes were reported. One patient with intracranial FIF was alive during follow-up but suffered poor muscle tone and underwent ventriculoperitoneal shunt [10]. One cases with multiple abdominal FIF died on postoperative day 32 due to hydrops [11]. Malignant recur as a yolk sac tumor was reported after retroperitoneal FIF resection [5]. We couldn't conclude that there was relation between outcome and the site of implant based on the limited cases. However, it is certain that 

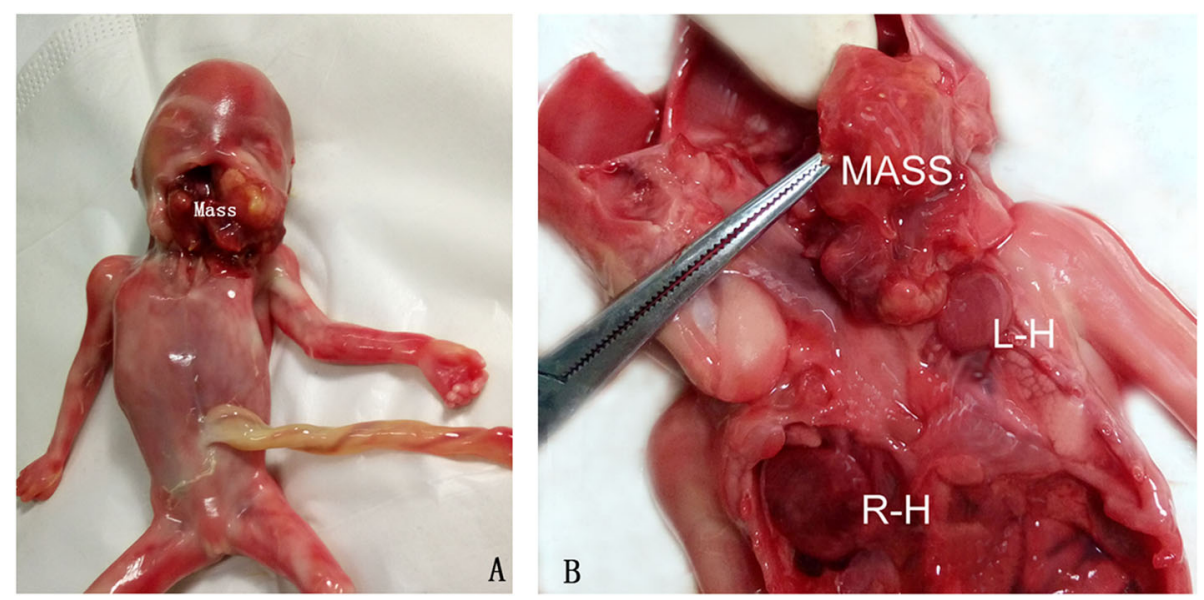

Fig. 3 Macroscopic examination found a solid mass between the oral and fetal chest (3A), with a rudimentary two-chambered heart at the lowest part of the mass (3B).L-H, left heart; $\mathrm{R}-\mathrm{H}$, right heart

the complication varied among the different locations. For abdominal FIF, abdomen distention, emesis and peritoneal inflammation may be associated. For cranial FIF, obstructive hydrocephalus and mental retardation may be associated. For thoracic FIF, dysphagia and even airway obstruction may occur and therefore emergency surgery is needed $[7,8]$. Also, for FIF with multiple or large mass, or with abundant blood supply, heart failure and hydrops is the associated risk.

With the advance of acoustics technology, ultrasound could be used to detect such malformation in utero. Most of cases with FIF were detected in 2nd and 3rd trimester [4]. Our case was demonstrated at 16 weeks' gestation, the most early gestation age reported so far. We may hypothesize that in severe cases like the one presented here, the condition may be suspected in the first trimester at the time of first trimester screening, if such essential examination is performed and if trained operators are involved. Prenatal ultrasound can identify rudimentary organs suspecting FIF from early pregnancy. Detection of fetal heart beat facilitates differential diagnosis with teratomas, providing essential information for parental consulting and management..

\section{Abbreviation}

FIF: Fetus in fetu

\section{Acknowledgements}

Not applicable.

\section{Authors' contributions}

LW and QZ performed the ultrasonic image. SZ and BL performed the histological examination, and were contributors in writing the manuscript. All authors read and approved the final manuscript.

\section{Funding}

Cooperation Project of Hunan Science Foundation and Zhuzhou (2017JJ4060). Ling Wang was the funding body, who performed and acquired ultrasonic image.
Availability of data and materials

The datasets used and/or analysed during the current study are available from the corresponding author on reasonable request.

\section{Ethics approval and consent to participate}

Written informed consent was obtained from the parents, and this study was approved by the institutional review board at the Second Xiangya Hospital of Central South University.

\section{Consent for publication}

Written informed consent was obtained from the parents. The parents gave consent for their personal or clinical details along with any identifying images to be published in this study.

\section{Competing interests}

The authors declare that they have no competing interests.

\section{Author details}

${ }^{1}$ Department of Ultrasound Diagnosis, Maternal and Child Health Center of Zhuzhou, 128 Station Road, Zhuzhou, Hunan, China. ${ }^{2}$ Department of Ultrasound Diagnosis, The Second Xiangya Hospital of Central South University, 139 Renmin Road (M), Changsha 410011, Hunan, China.

Received: 20 August 2019 Accepted: 19 November 2019

Published online: 29 November 2019

\section{References}

1. Spencer R. Parasitic conjoined twins: external, internal (fetuses in fetu and teratomas), and detached (acardiacs). Clin Anat. 2001;14(6):428-44.

2. Willis RA. The structure of teratomata. J Pathol Bacteriol. 1935;40:1-36.

3. Ji Y, Chen S, Zhong L, Jiang $X$, Jin S, Kong F, Wang Q, Li C, Xiang B. Fetus in fetu: two case reports and literature review. BMC Pediatr. 2014;14:88. https:// doi.org/10.1186/1471-2431-14-88.

4. Ruffo G, Di Meglio L, Di Meglio L, Sica C, Resta A, Cicatiello R. Fetus-in-fetu: two case reports. J Matern Fetal Neonatal Med. 2019;32(17):2812-9.

5. Hopkins KL, Dickson PK, Ball TI, Ricketts RR, O'Shea PA, Abramowsky CR. Fetus-in-fetu with malignant recurrence. J Pediatr Surg. 1997;32:1476-9.

6. Mills P, Bornick PW, Morales WJ, Allen M, Gilbert-Barness E, Johnson PK, et al. Ultrasound prenatal diagnosis of fetus in fetu. Ultrasound Obstet Gynecol. 2001;18(1):69-71.

7. Yu YR, Espinoza J, Mehta DK, Keswani SG, Lee TC. Perinatal diagnosis and management of oropharyngeal fetus in fetu: a case report. J Clin Ultrasound. 2018:46(4):286-91.

8. Kapoor V, Flom L, Fitz CR. Oropharingeal fetus in fetu. Pediatr Radiol. 2004; 34(6):488-91.

9. Prescher LM, Butler WJ, Vachon TA. Fetus in fetu: review of the literature over the past 15years. J Pediatr Surg Case Rep. 2015;3(12):554-62. 
10. Huddle LN, Fuller C, Powell T, Hiemenga JA, Yan J, Deuell B, Lyders EM, Bodurtha JN, Papenhausen PR, Jackson-Cook CK, Pandya A, Jaworski M, Tye GW, Ritter AM. Intraventricular twin fetuses in fetu. J Neurosurg Pediatr. 2012;9(1):17-23.

11. Gerber RE, Kamaya A, Miller SS, Madan A, Cronin DM, Dwyer B, Chueh J, Conner KE, Barth RA. Fetus in fetu: 11 fetoid forms in a single fetus: review of the literature and imaging. J Ultrasound Med. 2008;27(9):1381-7.

\section{Publisher's Note}

Springer Nature remains neutral with regard to jurisdictional claims in published maps and institutional affiliations.

Ready to submit your research? Choose BMC and benefit from:

- fast, convenient online submission

- thorough peer review by experienced researchers in your field

- rapid publication on acceptance

- support for research data, including large and complex data types

- gold Open Access which fosters wider collaboration and increased citations

- maximum visibility for your research: over $100 \mathrm{M}$ website views per year

At $\mathrm{BMC}$, research is always in progress.

Learn more biomedcentral.com/submissions 